\title{
SYNTACTIC SOLUTIONS FOR SUBJUNCTIVE CLAUSES IN THE ENGLISH VERSION OF CIEN AÑOS DE SOLEDAD
}

\author{
Agnieszka Kozera, Universidade da Coruña \\ Email: agnieszka.kozera@yahoo.com
}

\begin{abstract}
This study investigates a contrast between Spanish subjunctive clauses and their English correspondences in a Márquez's novel. English resorts to different grammatical solutions in order to convey the subjunctive character of the clause. The linguistic variations are going to be analysed in this paper from two perspectives: syntactic and semantic. The investigation aims at examining parallel constructions in the original and the rendition of Márquez's novel and classifying them into the corresponding syntactic groups. It intends to trace the semantic contexts of subjunctive occurrences in the English text.

Keywords: subjunctive; modality; modal system; contrast; indicative.
\end{abstract}

Título en español: Soluciones sintácticas para las frases de subjuntivo en la versión inglesa de Cien años de soledad

Resumen: Este estudio compara el modo subjuntivo en español y sus correspondencias inglesas en la novela de Gabriel G. Márquez. El modo subjuntivo en español difiere sensiblemente del inglés. Se analizan en este trabajo las distintas soluciones lingüisticas desde dos perspectivas: sintáctica y semántica. Se examinan las construcciones paralelas en la versión original y en la traducción de la novela de Márquez y se clasifican según sus propiedades sintácticas. Se intenta encontrar los contextos semánticos de las ocurrencias del subjuntivo en el texto inglés.

Palabras claves: subjuntivo, los verbos modales, estudio comparativo, indicativo.

\section{INTRODUCTION}

The aim of this paper is to consider the subjunctive mood in Spanish and its manifestations in the English language. The analysis focuses on the syntactic and semantic characteristics of subjunctive constructions and on the contrast between two different grammar systems. It intends to elaborate upon the reasons for the discrepancies between these languages as well as to search for the linguistic solutions compensating the lack of the examined grammatical issue in English. A particular interest is devoted to the study of the Márquez's novel Cien años de soledad and its English version (One hundred years of solitude). The subjunctive occurrences are examined in both texts.

Date of reception: 29 May 2010

Date of acceptance: 11 September 2010 
Contrastive studies, a relatively new branch of linguistics, still remain unexplored. Yet, the differences and similarities concerning grammatical structures of languages have served as a resource base for teaching and translational purposes. Every syntactic phenomenon in one language has its correspondences in other languages although they might not be marked by the same linguistic properties. These parallel structures are traced in order to collect the data useful in the translation process. The syntactic differences among languages caused by the specific nature of every language as well as its own historical evolution, indicate the contrasts and provide a variability of linguistic solutions for translational studies. The transposition of a text from a source into a target language cannot be adjusted to the syntactic and semantic characteristics of the former but resorts to the linguistic conditions typical of the latter.

As a first step to the study, the theoretical background on subjunctive mood in Spanish is provided. This part explores the main features of the grammatical problem, that is its forms and usage. The clauses carrying subjunctive and indicative markers are introduced as a support for the syntactic and semantic considerations over the mood distinction.

The notion of subjunctive mood in English poses certain problems as to its presence in the language system. Thus, other linguistic variations are developed in order to provide a grammatical balance. Hence, English resorts to the solutions which, pragmatically, bear the characteristics corresponding to Spanish subjunctive forms. These syntactical equivalents are presented here together with the basic historical changes leading to the discussed differences.

The contrastive analysis of the two versions of the same novel gives an insight into the parallel structures between the two texts. Since the novel under study is written in Spanish, the hypothesis might be that subjunctive constructions affect the English version. Hence, the paper poses a question as to the degree of syntactic and pragmatic relations reflected in the translated text. The issue of Spanish-English grammatical contrasts is manifested in the translational techniques which are strongly connected with the syntactic possibilities of a particular language.

\section{SUBJUNCTIVE MOOD IN SPANISH}

Various theories of the subjunctive in Romance languages have emerged. They depicted the irrealis mood as one in opposition to the indicative (realis). The former tends to express the future tenses or unreal situations and is regarded as a mood of subordination. However, the subjunctive is not only a syntactic issue, but also a semantic one. It deals with the meaning in the verbal structure. Subjunctive is more limited in the usage of tenses, it represents situations with the past or future orientation. It functions as the indicative in both independent and subordinate clauses. The choice of subjunctive or indicative form in subordinate clauses is determined by the semantic restrictions. Subjunctive mood represents hypothesis and the subjective value of reality. Thus, it is dependent on verbs of order, emotions, fear, doubt, in temporal or conditional clauses, with indefinite pronouns or adjectival structures. The distinction between indicative and subjunctive appears on the semantic and individual level (factual vs. virtual, objective vs. subjective), on the level of presence or absence of certain elements, of negation and interrogation (Navas 1990: 137-140). 
On the basis of Latin grammar, scholars introduced the rule of an agreement of the tenses (concordantia temporum). A verb in the main clause must be in temporal agreement with a verb in a subordinate clause, regardless of the form of the verb: indicative or subjunctive. Such a correspondence is present in both indicative and subjunctive constructions. Present and future forms of the verb venir (to come) take the present subjunctive: venga, present perfect - present perfect subjunctive: haya venido, past tense and conditional past subjunctive: vinieran/viniesen and past perfect - past perfect subjunctive: hubieran/ hubiesen venido. However, most speakers do not obey the concordantia rules selecting the appropriate tense according to the conveyed meaning not the tense-matching, as Gaya claims (Whitley 1986: 119).

The usage of Spanish subjunctive is restricted to the preceding expressions which require the following verb in the subjunctive form. They can be classified into the separate semantic groups. The most typical are: possibility and wish, advice, purpose or concessive clauses, as illustrated in the following examples $(1,2,3,4)$, respectively:

1) Tal vez a Ricardo le haya pasado algo (Perhaps something has happened to him); Ojála se murieran! (I wish they died) (Navas 1986: 36)

2) Te aconsejo que te calles (I suggest that you be quiet); Te sugiero que no vuelvas más (I suggest that you don't come back) (Ruano 1997: 44)

3) Te lo dije para que lo entendieras (I told you this so that you could understand); Para que no te quedes solo hemos decidido venir a ver la película (We have decided to come to see a movie so that you won't stay alone) (Ruano 1997: 184)

4) Pase lo que pase, nunca consentiré una escisión (I never agree to separation, whatever happens); Sea cual sea su postura, hay que respetarla (Whatever his decision is, we have to respect it) (Navas 1986: 38).

Apart from the mentioned above, the subjunctive encompasses the semantic fields of emotion/ volition (5 and 6), doubt (7 and 8), negation (9), indefiniteness (10 and 11) and hypothesis/ unreality (12 and 13):

5) Me encanta que entiendas de mecánica (I'm delighted that you understand mechanics)

6) Ellos quieren que les compraremos el cuaderno (They want us to buy them the notebook)

7) Dudan que pueda jugar al juego (They doubt that he can play the game)

8) No me parece que tenga suficiente dinero para comprar el coche (It doesn't seem to me that he has enough money to buy the car)

9) No veo a nadie que tenga el libro (I see no one that has the book)

10) Busco un gato que tenga un temperamento agradable (I'm looking for the cat that has a nice personality)

11) Necesito un lapicero que escriba en tres colores (I need a pencil that writes in three colours)

12) Fue imposible que hubiera leido el libro (It was imposible for her to have read the book) 
13) Esa chica me hablaba como si yo fuera tonto (That girl talked to me as if I were a fool) (Bustamante 1994: 118-121).

Spanish subjunctive as a mood expressing unreality, on the contrary to indicative, is closely related to future tense, since both are used to describe unreal actions or those not existing yet. Thus, in Spanish temporal clauses the verb takes the subjunctive form, whereas its English counterpart remains in indicative. As Durán (2000) claims, the probability of an action to be conducted may be examined on three levels. The highest probability corresponds to the present tense in the subordinate clause: I'm glad that she's buying the house (Me alegra que compre la casa), the lower probability chooses tense more distant from future, that is past: I would be glad if she bought the house (Me alegraria que comprara la casa) and finally, the lowest level signifies no probability because the sentence has past reference: I would have been glad if she had bought the house (Me hubiera alegrado que hubiera comprado la casa) (2000: 42).

\subsection{Spanish subjunctive and the issue of assertability}

Lunn (1989) considers a subjunctive mood as a mood of nonassertion. It is the speaker's attitude which determines the mood choice and it is the speaker who can modify the attitude towards the given information (1989: 687). Thus, it might be noticed that applying the mood of nonassertion in the assertive contexts, caused by the choice of the speaker, poses a questions as to the violation of the syntactic and semantic restrictions. Subjunctivizing the information does not involve tagging it as irrelevant, but "it is of limited usefulness in improving a hearer's representation of the world" (Lunn 1989: 690).

The relation between the mood choice and the semantic character of the proposition illustrates that the affirmative clauses are encoded in the indicative, whereas the not affirmative (non-assertive clauses) take the subjunctive form. It is crucial to emphasize that among the affirmative clauses are included those of doubt and order which impose the subjunctive use. Hence, the negation rules change the meaning of the sentence as well as the mood choice. A negative particle in the clauses of doubt removes the non-assertive nature, whereas the assertive sentence under negation rules is transformed into the sentence of doubt, as may be seen in the examples $(14,15)$ :

14) Creo que Martin ha leido ese libro vs. No creo que Martin haya leido ese libro

(I think that Martin has read that book vs. I don't think that Martin has read that book)

15) Dudo que Consuela sea culpable vs. No dudo que Consuela es culpable (I doubt that Consuela can be blamed vs. I don't doubt that Consuela can be blamed) (Terrel 1990: 152).

\subsection{Subjunctive or indicative?}

Villalta (2008) describes the choice of a mood as conditioned by certain predicates which require a certain syntactic form of the verb following them. However, there are predicates 
which take both, indicative and subjunctive, forms in their subordinate clauses. The change of the mood contributes to the change of the meaning of the whole clause, which is shown in the following examples:

16) Siento que te hayan hecho daño (I am sorry that they have hurt you)

17) Siento que va a haber un problema (I have the impression that there is going to be a problem)

18) Te digo que acabaré a tiempo (I tell you that I'll finish on time)

19) Te dije que acabaras a tiempo (I told you to finish on time) (Villalta 2008: 471).

20) Espero que venga mi hermano (I hope that my brother will come)

21) *Espero que vendrá mi hermano (I anticipate that my brother will come) (Villalta 2008: 511).

In examples 16 and 19 the subjunctive is used since the predicates are used in the semantic contexts requiring this mood. Here, sentir involves an emotive meaning and decir an order. Examples 17 and 18, on the other hand, are encoded in indicative because they express perception/ opinion and act of communication, respectively. The use of the verb esperar is illustrated in the examples 20 and 21 . The complement clause takes the subjunctive verb form when it expresses the emotive character (to hope) and in order to convey the sense of waiting and anticipating the indicative is used ${ }^{2}$.

\section{MOOD OR MODALITY? - THE CASE OF ENGLISH SUBJUNCTIVE}

It is assumed that a language system has either mood or modality ${ }^{3}$. English has developed a modal verbs system in order to compensate the lack of mood distinction. Yet, some historical traces of subjunctive clauses may be encountered in the contemporary language.

In present-day English examples closely related to subjunctive occur in hypothetical constructions, as if she were, in fixed formulae so be it and clauses introduced by that, especially in American English: I insist that he go (Crystal 1980: 420). In Modern English only few distinctive subjunctive forms survived (which were quite abundant in Old English). However, they are not used often. Present subjunctive in subordinate clauses refers to present and past time. Its form is identical with the base of the verb - bare infinitive. It only differs from indicative in the third person singular. The inflection of the verb to be is an exception (McArthur 1992: 830).

Szwedek (1972: 108) claims that subjunctive could be distinguished from indicative in the Early New English, in the $2^{\text {nd }}$ person singular, but only with the pronoun thou and - est ending in the verb and also in the $3^{\text {rd }}$ singular. Past subjunctive varies from indicative form in the $1^{\text {st }}$ and $3^{\text {rd }}$ singular (were vs. was) and in the $2^{\text {nd }}$ with thou (were vs. wert). In the persons where the forms are identical with the indicative, there is no mood distinction. In Old English subjunctive functioned as a way of expressing various subjective issues,

Rarely encountered in spoken Spanish.

3 In this paper, I will not discuss the concept of modality and modal verbs in detail but, only by mentioning them briefly, focus on the ways of expressing the subjunctivized information in English. 
uncertainty, diffidence and hesitation. It might be treated as something possible which was not a fact.

According to Zandvoort (1964: 87), subjunctive is used in nominal subordinate clauses which depend on the main clauses expressing will, for example. It may occur as well in adverbial clauses of condition or concession:

So long as the volume hold together, I am not troubled as to its appearance Though everyone desert you, I will not.

Zandvoort (1964: 88) describes three forms of subjunctive categorized by its usage:

- optative (expressing wish); An army lieutenant demanded that the flag be lowered

- potential (expressing possibility); The inventor may, if he live in London, search the files

- irrealis (expressing unreality); I wish it were over.

Subjunctive requires a tense system as in the indicative but transformed to a different mode and kind of perspective. The assumption is that every indicative should have its corresponding subjunctive counterpart (Whitley 1986: 118). It is syntactic not notional category. English subjunctive is by no means symmetrical to Spanish.

Thus, English modals seem to be the main resource for conveying modal meanings and a speaker's attitude (Rabadán 2006: 264). They express necessity, permission, possibility, obligation, as well as the attitude to the information or its judgment.

\subsection{Periphrastic forms of subjunctive}

Since being a non-inflectional language, English resorts to other linguistic solutions in order to convey the subjunctive character of the information. It is encoded in periphrastic forms, mainly in modal verbs.

$$
\text { May + infinitive }
$$

This construction resembles optative subjunctive and expresses a wish encoded in present time: may angels protect you; may he say the truth. Purpose, possibility or concession are also expressed with may + infinitive: this I thought fit to premise that the reader may not judge too hastily...; my reader may remember that he has seen in one of my papers a complaint...

Past form might is used similarly in the contexts concerning past. It may refer to present or future when it describes more remote possibility or concession: ...so that in some cases it might be proper to say... (Charleston 1941: 151-154).

Shall/ should + infinitive

This structure is used after verbs of wishing, proposing and when the action is uncertain. It appears in relative constructions where it implies doubt and uncertainty and refers to 
something unreal or imaginary: ... which should restore him more expeditiously than could be imagined; ...that had we gone that way which we should have gone.

It is also used after verbs of opinion or after impersonal expressions: it is possible, probable, etc.: I have a mind that you should stay to hear what I have to say to you; it is impossible he should think his merit sufficiently rewarded; one would think potatoes should be all their bread...

Adverb clauses of time and condition entail should + infinitive, as well: ...to put off his day until he shall receive..; ... for if I should be taken with a fresh of wind, I might neither reach one or other; this I hope to do before I sleep, but if it should happen otherwise , I charge thee.. (Charleston 1941: 155-159).

$$
\text { Can/ could + infinitive }
$$

The above structure conveys the idea of possibility where the use of past form emphasizes the remoteness and vagueness of this possibility: I could wish you would furnish us with more notes...; ...I could wish there might be a suspension of physic for some years...

Indicative forms quite often have a function of the subjunctive and the other way round, the subjunctive form of to be with an indicative function, which remains as a trace of the older usage (Charleston 1941: 160-163).

\subsection{Syntactic and semantic aspect of English subjunctive constructions}

Originally, English subjunctive denoted a variety of attitudes of the speaker towards the content of the message, such as doubt, possibility or indetermination. Throughout the ages present and past forms lost their endings, thus indicative forms or modals were used as their substitutes. Subjunctive has converted into the analytical mood. Nowadays, constructions in English which appear to be relevant to former subjunctives are contextual equivalents of Spanish subjunctives (Durán 1941: 39).

English subjunctive is characterized by poor paradigm distinction. It is due to the fact that present subjunctive and bare stem are identical whereas past subjunctive is reduced to the $1^{\text {st }}$ and $3^{\text {rd }}$ person singular of be. The use of bare infinitive as subjunctive bears resemblance to imperative constructions. Contrary to imperatives, subjunctive appears in subordinate or embedded clauses, except for optative. Syntactically, it is realized as a direct complement after verbs like: order, command, demand, insist, recommend, require, authorize, suggest or as adverbial too. It is illustrated in the examples below:

22) They demand that the plane take off now

23) Geoff insisted that she be on time

24) The judge orders that you not be taken to prison

25) The law requires that the prisoners not have anything in their pockets

26) The doctors have ordered that the boy not be watching TV so late in the evening

27) The antiquarian insists that he not arrive late (Castillo 2003: 460). 
There are also other types of subordinate clauses where the subjunctive occurs:

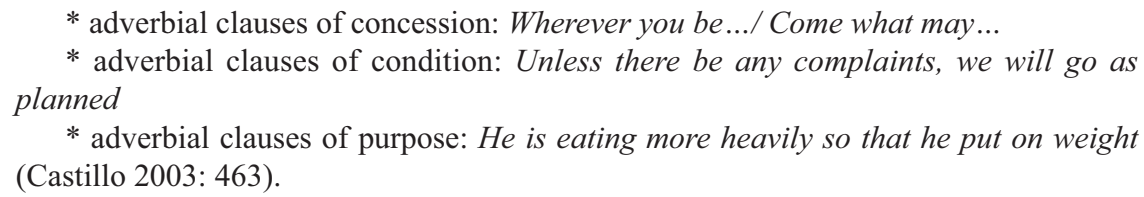

Past subjunctive is preserved in present-day English but limited only to the verb to be. It is used to convey the unreal and hypothetical meanings as well as to express wishes:

* complement clauses of wish: I wish I were not so sensitive to changes

* hypothetical comparative clauses: She works as if she were to be promoted soon

* conditional clauses: If he were honest, we would all trust him (Castillo 2003: 464).

What distinguishes subjunctive from imperative, apart from occurrence in subordinate clauses, is a division between present and past form and lack of the operator $d o$. An ordinary verb is used in the negative form and $d o$ is not needed:

Don't arrive late! vs. The antiquarian insists that he not arrive late - presence of do in imperative and its lack in subjunctive constructions (Castillo 2003: 463).

The semantics of subjunctive is connected with the realis or irrealis. The higher possibility is encoded in present subjunctive, whereas the lower one or the impossibility in the past. Thus, the wish is regarded as realizable when there is no optative marker and present subjunctive is used: May she rest in peace; Long live Spain (Haverkate 2002: 32).

\section{ENGLISH-SPANISH CONTRAST - STRATEGIES FOR CONVEYING THE SAME MESSAGE}

It should be stated here that the contrast between languages is caused by their different origins or belonging to distinct language families. Yet, even the languages of the same families may not be alike in their grammatical systems. The fact that English and Spanish belong to the same Indo European language family allows them to display certain similarities in syntactic or semantic structures. Any historical, linguistic and economic processes may contribute to the higher or lower grade of relatedness. Each of these languages has a different subfamily (Germanic and Latin, respectively) and its own way of developing. Various factors, including other languages influences or area where it is spoken, determine this development. Since given features are alike and can be shared by many languages, others can be unique and ascribed only to one.

Spanish as a Latin language retains the inflection of the verb. This feature contrasts it with English as a non-inflectional language. Since the latter preserves the same verb forms for all persons, there is no need to distinguish between indicative and subjunctive. 
Another important point is that Old English and the $17^{\text {th }}$ century English were abundant in subjunctive forms which began disappearing in course of history. Phrases present in contemporary language are the remnants of historical processes and the manifestation of historical influences. This is caused by the fact that English used to be an inflectional language. Today, the only survived past subjunctive form is were for hypothetical and unreal clauses and some fixed expressions. It might be noticed that semantically subjunctive is present in both languages although its syntactic form is peculiar only to Spanish.

\subsection{Syntactic English-Spanish contrasts}

Below I present a list of the most common English syntactic solutions for Spanish subjunctive. These contrastive examples are based on Durán (2000) and Arranz (1986).

- that clause in English vs. subjunctive in Spanish: It is necessary that I do it (Es necesario que yo lo haga); I demand that you tell me (Es necesario que me lo cuentes)

- to + infinitive in English vs. subjunctive in Spanish: It's logical for you to judge by the facts (Es logico que usted juzgue por el resultado externo); It is possible for my mother to do it (Es posible que mi madre lo haga)

- -ing form in English vs. subjunctive in Spanish: It's no good trying to answer you (Es inútil que yo te conteste)

- modal auxiliary in English vs. subjunctive in Spanish: They may be in danger (Es possible que estén en peligro); It's natural you should think about it (Es natural que penseís en ello)

- adverbial clauses take indicative in English and subjunctive in Spanish: Let's go wherever you want to (Vamos a donde quieras)

- clauses expressing indefiniteness: Whatever joke you pull - any joke that you do (Cualquier broma que le hagas); whatever happens (sea lo que sea)

- clauses expressing finality take indicative in English and subjunctive in Spanish: There are cheaper prices so that people will go (Hay precios especiales para que acuda la gente)

- hypothesis is expressed by subjunctive were or past modals in English and past subjunctive in Spanish: I wish it were possible (Ojála fuera eso posible!); I wish I could (Ojála pudiera!)

- independent clauses introduced by que in Spanish are realized with imperative in English: Let him go ( Que se vaya); Have them come in (Que pasen) (Durán 2000: 144)

- after verbs of senses, thinking and speaking in negative form Spanish uses subjunctive whereas English takes indicative: I don't think they'll come (No creo que vengan); I don't see you're pale (No noto que estés pálido) 
- with verbs of doubt or suspicion- indicative in English and subjunctive or indicative in Spanish: I doubt he is right (Dudo que tenga razón); I suspect he is the one to blame (Sospecho que tiene (tenga) la culpa)

- in questions offering help in English shall + infinitive is used: Shall I fetch your coat for you? (Quiere que le traiga su abrigo?); to indicate possibility may + infinitive: It may rain tomorrow (Puede que llueva mañana)

- verbs of order, determination, expectation in English have accusative + infinitive construction: I expect him to arrive soon (Espero que llegue pronto); I want you to come immediately (Quiero que vengas immediatamente) - here subjunctive is expressed directly by to infinitive

- order, command or suggestion is expressed by for + accusative + to infinitive or by for + gerund: He gave orders for the prisoners to be set freel He gave orders for the setting free of the prisoners (Dio ordenes de que se pusiera en libertad a los prisoneros)

- construction for + accusative + to infinitive is used also in English as a translation of Spanish impersonal to be + adjective construction: It is better for him to listen to what you have to say (Es mejor que te escuche lo que tienes que decir); It was madness for me to go (Fue una locura que fuera)

- that in English exclamations: That I could live to see my son married! (Que pudiera vivir para ver a mi hijo casado!)

- may exclamations: May he live long! (Que viva mucho tiempo!) (Arranz 1986: 142-148).

English subjunctive, in the majority of the cases, is realized by: to infinitive, gerund, that embedded clauses, modal verbs constructions, indefinite pronouns and hypothetical clauses with past subjunctive of the verb to be. Exclamation version of Spanish subjunctive is conveyed by periphrastic may, which can be observed in the last example above. The original subjunctive is removed from English system and the expressions preserved, carrying this form, are adapted as fixed formulas: suffice it to say, long live Spain, God save the Queen, so be it, if need be, etc.

\section{FROM SOURCE INTO TARGET LANGUAGE - METHODOLOGY AND ANALYSIS OF DATA}

In this section I will focus on the Márquez's novel Cien años de soledad and its translated English version, examining the subjunctive clauses extracted from the source text and their renditions in the target language. By this analysis, I will try to find an answer to the problem of how to translate linguistic items into the language where they do not exist. Is the English version of the novel adjusted to the target language conditions or is it affected, to some extent, by the source text? Furthermore, this analysis aims also at evaluating the degree to which grammar is influenced by the literary aesthetic devices. 


\subsection{Methodology of research}

The novel of Gabriel García Márquez Cien años de soledad and its English version One hundred years of solitude translated by G. Rabassa are the tools for this contrastive study. The instances of subjunctive structures are extracted from the original and contrasted with their English equivalents. They are chosen randomly from the whole book. The choice of the text has been conditioned by two factors. First, the novel had to be written in Spanish since the examined phenomenon is more typical of Spanish than English. Secondly, the author and the title ought to be known in both cultures as a representative example of the literary fiction.

By no means is the list of subjunctive occurrences exhaustive here. The examples under study are chosen in order to illustrate the syntactic differences or similarities between the languages. The repetitive instances have been omitted or mentioned only once. They have been examined with the translated versions on two layers: syntactic (how the Spanish subjunctive is realized in English) and semantic (in which semantic field subjunctive dominates over indicative).

\subsection{Data analysis}

I have encountered and examined 76 occurrences of the subjunctive mood in the Spanish novel where 26 are encoded in present subjunctive and 50 in the past. Below I enclose the whole list with the translations and annotations ${ }^{4}$.

1) ...que dejo a su disposición para que pudiera servirse del astrolabio - which he left so that he would be able to make use of the astrolabe (past subjunctive - would + infinitive)

2) todo el mundo se sorprendió de que hubieran podido encontrar... - everyone was surprised that they had been able to find... (past perfect subjunctive - past perfect, passive voice)

3) no faltó quien lo considerara... - there were many who considered... (past subjunctive - past simple)

4) uno no es de ninguna parte mientras no tenga... - a person does not belong to a place until there is... (present subjunctive - present simple)

5) diles que vengan - tell them to come (present subjunctive - infinitive)

6) estaban obstinados en que su padre los llevara a conocer... - they insisted that their father take them to see... (past subjunctive - infinitive)

7) hubieran sido felices desde entonces si la madre de Ursula no la hubiera aterrorizado... - they would have been happy from then on if Ursula's mother had not terrified her... (past perfect subjunctive - past perfect)

8) queria que ella fuera su madre - he wanted her to be his mother (past subjunctive - infinitive)

9) deseaba de todo corazón que la puerta estuviera atrancada - with all his heart he wanted the door to be barred (past subjunctive - infinitive, passive voice)

\footnotetext{
4 The examples are taken from the electronic versions of Cien años de soledad and One hundred years of solitude, pages omitted.
} 
10) que Dios te la conserve - may God preserve you just as you are (present subjunctive - may + infinitive)

11) les pidió que los dejaran tranquilos - asked them to leave them alone (past subjunctive - infinitive)

12) ojála fuera cierto - I hope it's true (past subjunctive - present simple)

13) se determinó que fuera el quien dirigiera la repartición - it was decided that he should be the one in charge of the distribution (past subjunctive - should + infinitive / noun phrase)

14) a quienes Dios tuviera en su santo reino - may God keep them in his holy kingdom (past subjunctive - may + infinitive)

15) ni conocían a nadie que se llamara como el remitente - nor did they know anyone by the name of the sender of the letter (past subjunctive - noun phrase)

16) era como si la casa se hubiera llenado de visitantes - it was as if the house were full of visitors (past perfect subjunctive - past subjunctive)

17) trabajaron tanto que pronto no tuvieran nada que hacer-they worked so hard that soon they had nothing else to do (past subjunctive - past simple)

18) aunque nunca permitió que le hicieran un daguerrotipo - although she never permitted them to make a daguerreotype (past subjunctive - infinitive)

19) todo el mundo se extrañaba de que fuera... - everybody thought it strange that he was... (past subjunctive - past simple)

20) para que nunca faltaran los alimentos en la casa - so that there would never be a lack of food (past subjunctive - would + infinitive)

21) no porque tenga en la puerta esos bandoleros - not because you have those bandits with shotguns at the door (present subjunctive - present simple)

22) cuando me muera - when I die (present subjunctive - present simple)

23) otros para que Dios no fuera a tomar-others so that God would not take the disdain (past subjunctive - would + infinitive)

24) le pareció una exageración que su suegro se hiciera enviar - it seemed an exaggeration to him that.... had them sent (past subjunctive - past perfect)

25) si yo fuera liberal - if I were a liberal (past subjunctive - past subjunctive)

26) procura que lo encontrémos mejor - try to have it in better shape (present subjunctive - infinitive)

27) Dios quiso que José Arcadio y Rebecca se casaran - God willed that JA and Rebecca should get married (past subjunctive - should + infinitive)

28) es mejor que esta noche dejes - it will be better if you leave... (present subjunctive - present simple)

29) se me olvidó decir que si nacía mujer la pusieran... - I forgot to say that if it was a girl they should name her... (past subjunctive - past simple)

30) como usted diga - as you say (present subjunctive - present simple)

31) viva el partido liberal-long live the Liberal Party (present subjunctive - present subjunctive)

32) el pidió que le leyera... - he asked her to read... (past subjunctive - infinitive)

33) tan pronto como pusiera... - as soon as he put... (past subjunctive - present simple)

34) trataban de que el país creyera en la reconciliación - tried to make the country believe in reconciliation (past subjunctive - infinitive) 
35) lástima que no sea un conservador - what a pity that he is not a Conservative (present subjunctive - present simple)

36) es casi como si fuera tu madre - it's almost as if I were your mother (past subjunctive - past subjunctive)

37) todavía no ha nacido el hombre que me ponga las manos encima - the man hasn't been born yet who can lay hands on me (present subjunctive - can + infinitive)

38) ojála fuera el coronel - I only wish it was colonel (past subjunctive - past simple)

39) no esperaba que su actitud conciliatoria pudiera impedir lo inevitable-he did not expect that his conciliatory attitude would be able to prevent the inevitable (past subjunctive - would + infinitive)

40) no olviden que mientras Dios nos dé vida... - don't forget that as long as God gives us life... (present subjunctive - present simple)

41) antes de que el las concibiera... - before he thought of them (past subjunctive - past simple)

42) es natural que esté lloviendo - it's natural for it to be raining (present subjunctive - for + infinitive)

43) que las aprovechen - I hope you can get some advantage out of them (present subjunctive - can + infinitive)

44) ninguna manifestación que pudiera... - any other manifestation that might... (past subjunctive - might + infinitive)

45) le pidió al coronel que lo llevara a ver los fusilamientos-asked colonel to let him see an execution (past subjunctive - infinitive)

46) nadie debe conocer su sentido mientras no hayan cumplido cien años - no one must know their meaning until he has reached one hundred years of age (present perfect subjunctive - present perfect)

47) ojála se meta de cura para que Dios entre por fin a esta casa-let's hope that he becomes a priest so that God will finally come into this house (present subjunctive - present simple; will + infinitive)

48) no sea que en la otra vida no vayas a cobrar... - so that you will not collect for this squandering in the other life (present subjunctive - will + infinitive)

49) es como si el tiempo diera vueltas... - it's as if the time had turned around (past subjunctive - past perfect)

50) más fascinante que hubiera podido concebir la imaginación - the most fascinating woman that imagination could conceive (past perfect subjunctive - past modal)

51) el pacto no logró que Fernanda se incorporara a la familia - the pact did not succeed in incorporating Fernanda into a family (past subjunctive - gerund)

52) no es justo que ahora me vengan con este recuerdo - it's not right for them to come to me with that memory now (present subjunctive - infinitive)

53) todo lo que ocurrió antes de que volviera pintado - all that happened before he came back painted (past subjunctive - past simple)

54) que no vuelva a pisar este hogar, mientras tenga la sarna de los forasteroshe won't ever come into this house again, as long as he carries the rash of the foreigners (present subjunctive - present simple)

55) lo llevó sin que viniera a cuento a pensar... - led him to think about the war without his realizing it (past subjunctive - gerund) 
56) le sugirió a Meme que anticipara un concierto - she suggested to Meme that she move up a clavichord concert (past subjunctive - that clause: present subjunctive)

57) que nadie se haga ilusiones - let no one have any illusions (present subjunctive - let + infinitive)

58) es como si el mundo estuviera dando vueltas - it's as if the world were repeating itself (past subjunctive - past subjunctive)

59) como si cumpliera un pacto implícito, llevó a su hijo... - as if she were fulfilling an implicit pact, she took her son... (past subjunctive - past subjunctive)

60) que no te vea - don't let Fernanda see you (present subjunctive - let + infinitive)

61) de modo que pudieran secarse los pisos - so that they could dry the floors (past subjunctive - past modal)

62) qué quieres que haga? - what do you want me to do? (present subjunctive infinitive)

63) esperanza de que las barajas vieran mas que los cavadores - with the hope that the cards would see more than the diggers (past subjunctive - could + infinitive)

64) bendito sea Dios! - Lord save us! (present subjunctive - present subjunctive)

65) que compren las tortugas más grandes, que vengan las forasteros, que se sienten a la mesa a comer cuantas veces quieran - buy the largest turtle, let strangers come, and sit down to eat as many times as they want (present subjunctive infinitive)

66) es hora de que empieces aprender - now it's time for you to start learning (present subjunctive - for + infinitive)

67) ...quienes pagaran ... - who paid (past subjunctive - past simple)

68) para que nadie fuera a conocer - so that no one would learn ... (past subjunctive - would + infinitive)

69) no hay humillación que no la merezca una concubina - there is no humiliation that a concubine does not deserve (present subjunctive - present simple)

70) a cualquier hora que entrara - any hour that would go into (past subjunctive - would + infinitive)

71) estaba pendiente de que tuviera un buen par de zapatos - she saw to it that she had a good pair of shoes (past subjunctive - past simple)

72) no encontró quien recordara a su familia - Aureliano could not find anyone who remembered his family (past subjunctive - past simple)

73) no creyó que se estuviera burlando de alguien - the only one who did not think he was making fun of somebody (past subjunctive - past continuous)

74) ningún misterio en el corazón que fuera impenetrable para ella - there was no mystery in the heart that was impenetrable for her (past subjunctive - past simple)

75) nadie hubiera podido presentir su decisión - no one could have foreseen his decision (past perfect subjunctive - could + perfect infinitive)

76) cualquier lugar en que estuvieran - wherever they might be (past subjunctive - might + infinitive) 
The source text is prolific in subjunctive constructions, whereas its English version replaces the original structure by other linguistic solutions. In most cases, it is realized by modal verbs: might, should, may, can, could, infinitive or gerund constructions or indicative present or past tense. In order to render indefinite expressions, the translator resorts to indefinite pronouns, as: wherever, whatever. As can be seen in the following graph, the indicative constructions outnumber other grammatical solutions.

Graph 1. English alternatives to Spanish subjunctive clauses.

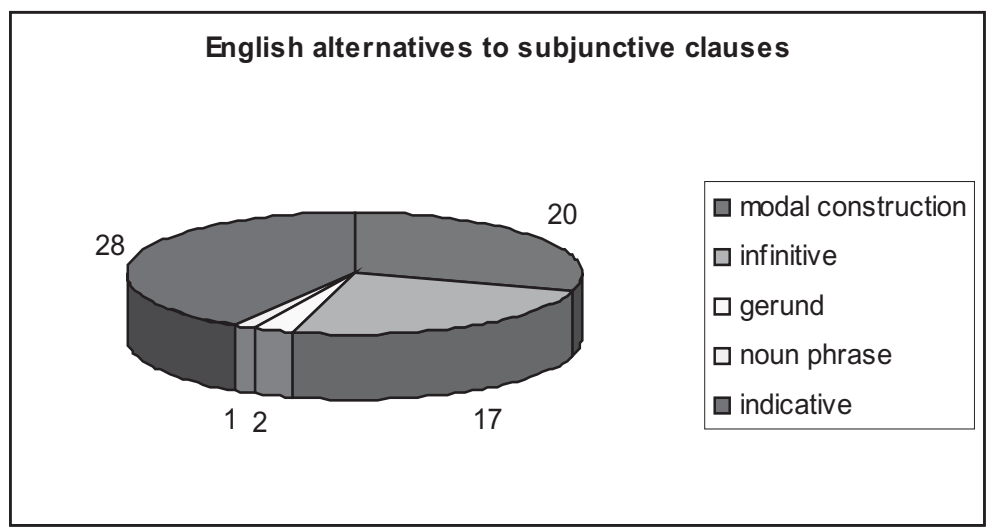

English past subjunctive of the verb to be is used in hypothetical clauses or those expressing wishes, as the examples 16, 25, 36, 58 and 59 show. Present subjunctive is preserved in the target text only where it denotes a fixed phrase: instances 31 and 64. Example 56 illustrates that clause with subjunctive (that she move) and it is the only occurrence of this type that has been found in the translation. The next example (57) draws our attention due to the let + infinitive construction (let no one have) which cannot be classified as a subjunctive but rather as an example of imperative clause.

Interestingly, I have found at least two occurrences where the character of the translation depends not on the grammatical restrictions but on the free choice of the translator. One of these is example 38 where the past simple tense, not past subjunctive, has been chosen in order to convey the wish: I wish it was..., whereas in the instance 64 the translation is not faithful: bendito sea Dios! (God be blessed), the translator uses a fixed expression Lord save us!

All syntactic English solutions are shown in the table below. 
Table 1. Sp. subjunctive vs. Eng. constructions in Márquez's novel.

\begin{tabular}{|c|c|c|c|c|c|}
\hline language & $\begin{array}{c}\text { Present } \\
\text { subj. }\end{array}$ & Past subj. & $\begin{array}{c}\text { Modal construc- } \\
\text { tions }\end{array}$ & $\begin{array}{c}\text { Infinitive/ } \\
\text { gerund/ } \\
\text { other* }\end{array}$ & Indicative \\
\hline English & 3 & 5 & 20 & $17 / 2 / 1$ & 28 \\
\hline Spanish & 26 & 50 & - & - & - \\
\hline
\end{tabular}

The majority of the analyzed examples from the source text pertains to emotion and volition and to unreal, hypothetical situations, whereas in the target text the subjunctive concerns mainly the latter semantic field and is encoded in the past tense (were). The semantic results can be seen in table 2 .

Table 2. The number of subjunctive forms in English and Spanish examined texts.

\begin{tabular}{|c|c|c|c|c|c|c|c|}
\hline $\begin{array}{c}\text { Subj. } \\
\text { mood }\end{array}$ & $\begin{array}{c}\text { present } \\
\text { sub- } \\
\text { junctive }\end{array}$ & $\begin{array}{c}\text { past sub- } \\
\text { junctive }\end{array}$ & $\begin{array}{c}\text { emotion, } \\
\text { volition }\end{array}$ & $\begin{array}{c}\text { pur- } \\
\text { pose }\end{array}$ & $\begin{array}{c}\text { indefini- } \\
\text { teness/ } \\
\text { negation }\end{array}$ & $\begin{array}{c}\text { tem- } \\
\text { poral/ } \\
\text { other* }\end{array}$ & total \\
\hline $\begin{array}{c}\text { Cien } \\
\text { años de } \\
\text { soledad }\end{array}$ & 26 & 50 & 27 & 4 & $8 / 13$ & $6 / 18$ & 76 \\
\hline $\begin{array}{c}\text { One } \\
\text { hundred } \\
\text { years of } \\
\text { solitude }\end{array}$ & 3 & 5 & 1 & - & $-/-$ & $-/ 7$ & 8 \\
\hline
\end{tabular}

* other: fixed expressions and hypothetical clauses

As the figures show, the English subjunctive is present only in the fixed expressions or hypothetical conditional clauses. Although it is disappearing from everyday language, its function is conveyed in the indirect way with a wide range of grammatical solutions, mentioned above.

\section{CONCLUDING REMARKS}

Subjunctive mood in Spanish and its realization in English have been examined in this paper. The former adopted a Latin conjugation system, has developed a mood system with a range of inflectional endings. The latter, on the other hand, lost inflection in course of history and removed a mood which has been replaced by a highly developed modal verbs system. Syntactically, it is expressed by other linguistic constructions.

The analysis of the original and the translation of Márquez's novel served as a practical tool verifying a theory and evaluating the differences between the academic and everyday language entailed in the prose. The principal conclusion, which ensues from this study, is that the rendered text is adjusted to English linguistic conditions. The Spanish subjunctive is translated as an indicative construction, using present or past tenses, modal expressions 
or as a non-finite clauses: with infinitives and gerunds. Only in few cases, can we notice the subjunctive clause in the translation: for hypothetical/ unreal uses and fixed expressions. One instance out of 76, illustrates the choice for that subjunctive clause (ex. 56).

The grammatical restrictions are imposed on the translator in the majority of the cases. Yet, as can be seen in the example 38, it is the translator's (or it might be supposed that the speaker's in everyday situations as well) choice between the subjunctive and indicative option. No grammar rules are here violated, since both are correct and acceptable. This observation leads us to the other conclusion that the subjunctive occurrences are only the traces of the $17^{\text {th }}$ century language whereas the contemporary one reduces their usage from nearly every semantic field.

\section{REFERENCES}

\section{Primary sources:}

MÁrquez G. Cien años de soledad. http://www.eltutordebangkok.com/music/books/ Soledad.pdf

One hundred years of solitude. Translated by G. RaBAsSA. http://tomgud. googlepages.com/OneHundredYearsofSoli.pdf

\section{Secondary sources:}

Arranz, A. 1986. Manual de Gramatica Inglesa Comparada. Madrid: EDI-6.

Bustamante, P. and A. Gunner 1994. Spanish Subjunctive in Context. London/ New York: University Press of America.

Castillo, C. 2003. English Syntax for Spanish Speakers: A Comparative Introduction. Bern/ New York/ Oxford: Peter Lang Pub Inc.

Crystal, D. 1980. A dictionary of Linguistics and Phonetics. Oxford: Blackwell Publishers.

Charleston, B. 1941. Studies on the Syntax of English Verb. Bern.

DuRÁn, J.R. 2000. Los tiempos de futuro y la modalidad en español y en ingles. Vigo: Universidade de Vigo.

Haverkate, H. 2002. The Syntax, Semantics and Pragmatics of Spanish mood. Amsterdam/ Philadelphia: John Benjamin's Publishing Company.

LunN, P. V. 1989. "Spanish mood and the prototype of assertability". Linguistics- an interdisciplinary journal of language science 27: 687-702.

McArthur, T. 1992. The Oxford Companion to the English Language. Oxford University Press.

Navas, R. 1986. El subjuntivo castellano. Salamanca: Publicaciones del Colegio de España. 
1990. "El subjuntivo castellano". Indicativo y subjuntivo. Ed. I. BosQue. Madrid: Taurus Universitaria. 107-141.

RABADÁN, R. 2006. "Modality and modal verbs in contrast: mapping out a translationally relevant approach English-Spanish". Language in Contrast 6, 2: 261-306.

Ruano, A. 1997. El subjuntivo en español. Salamanca: Edificiones Colegio de España.

Szwedek, A. 1972. "The Subjunctive in English". Studia Anglica Posnaniensia 4: 107-113.

Terrel, T. 1990. “Análisis semántico del modo en español”. Indicativo y subjuntivo. Ed. I. BosQuE. Madrid: Taurus Universitaria. 145-163.

Villalta, E. 2008. "Mood and gradability: an investigation of the subjunctive mood in Spanish". Linguistics and Philosophy 31, 4: 467-552.

Whitley, S. 1986. Spanish - English Contrasts. Washington: Georgetown University Press.

ZANDVOORT, R. W. 1964. A handbook of English grammar. Groningen: J.B. Wolters. 